\title{
17 \\ Reading indigeneity in nineteenth-century British Guiana
}

\author{
Manu Samriti Chander
}

\begin{abstract}
Innocence the magic charm is, Keeping sorrow's form at bay; By its influence, every harm is Banished ruthlessly away; Ill and danger fright her not, Happy is her simple lot.
\end{abstract}

-E.M. ${ }^{1}$

'By the Lake: An Indian Eclogue' by 'E.M.' appeared in the British Guianese newspaper the Colonist in 1882 and was not, to my knowledge, ever republished. It did not really need to be. Its central trope - the Indigenous subject as innocent, childlike, and idle - is so often repeated in settler descriptions of native peoples, so unextraordinary, that the poem hardly bears multiple readings. Things get a bit more interesting, however, when we consider that its author was not a white settler but an Afro-Creole who would go on to be hailed as the first real British Guianese poet and, in the words of Arthur Schomburg, 'one of the greatest Negro poets in history'. 'E.M.' was Egbert Martin, and, as I discuss below, his claim to represent British Guiana was founded precisely on the erasure of the Guianese native, or 'Amerindian'. ${ }^{3}$

This process of erasure, I argue, was not simply a consequence of a mode of poetic representation that figured the Amerindian as an object of knowledge. The rise of periodical culture in nineteenth-century British Guiana came to ground ideas of humanity in the capacity to read and thereby participate fully in the social life of the colony. Within this framework Indigenous peoples were understood as essentially illiterate, even as colonial missionaries sought to educate British Guianese Amerindians. As we see in the writings of a missionary such as John Henry Bernau, Christianisation was imagined to precede civilisation, which meant that converted Amerindians were always in danger of falling back into a pre-civilised state. Martin too failed to imagine the Amerindian as a fully literate, Christianised subject. The equation of a narrowly defined literacy with the category of the 
human, then, figures Indigenous peoples as always already 'read' - that is, as available for reading, and constitutively, non-reading.

\section{The making of Guianese reading audiences}

In 1881, the first daily newspaper produced in British Guiana, the Demerara Daily Chronicle, noted in its Prospectus that:

As education has become more widely diffused among the people, the reading population has slowly but steadily increased, and to a much larger portion of the community than heretofore a daily paper has thus become a necessity. Hitherto, however, no attempt has been made to produce a daily journal at a price sufficiently moderate to bring it within reach of all the classes and sections of our Colonial Society. This want the CHRONICLE is intended to supply. ${ }^{4}$

The seemingly laudable efforts of a newspaper like the Demerara Daily Chronicle to reach 'all the classes and sections of our Colonial Society' must be read as part of an effort to outsell its less frequent weekly and monthly competitors and, at the same time, to shape the reading public into an ideologically coherent whole. Of course, the Daily Chronicle's competitors were engaged in the very same project, which created a dynamic, conflictual, and continually shifting cultural field.

We can trace the emergence of a new phase of literary modernity to the rise of competing periodicals, which compels audiences, as Jon Klancher writes, 'to define themselves according to the interpretive mode they possess and the interpretive strategies thorough which that mode somehow allows them to "read" other audiences'. ${ }^{5}$ It is precisely when readers begin to understand themselves in relation to discrete cultural groups possessed of discrete tastes and, at the very same time, a broader 'imagined community' that the promises of a unified nation become inextricably bound to literacy. ${ }^{6}$ The modern nation coalesces, then, not despite a diversity of 'interpretive strategies', but because this diversity is understood to be a characteristic of the modern liberal democracy. Reasonable debate - no matter how contentious and conflictual - is not only tolerable but desirable. In the west this emergence is generally understood to be a late-eighteenth-century phenomenon. ${ }^{7}$

In British Guiana a newly dynamic public sphere starts to appear after emancipation in 1838. Nigel Westmaas offers a number of reasons for this development, including the appearance of the first Black newspaper (the Freeman Sentinel), technological advancements in printing in the colonies, and the rise of a new Black middle class, especially in the later decades of the nineteenth century. ${ }^{8}$ Despite the fact that formal literacy remained the privilege of a small part of the population throughout the century, there were 
dozens of newspapers circulating during the period, many with short runs that, according to Westmaas, attest to the continually shifting and complexifying nature of the Guianese reading public. ${ }^{9}$

At the same time that the reading public was expanding beyond settler colonials to include a greater number of Creole readers, the status of the native Amerindian population was changing. Prior to emancipation, certain protections seemed to suggest that the Amerindian, while not quite human, had more innate value than the enslaved African within the British imagination. ${ }^{10}$ In an 1811 letter concerning Governor Henry William Bentinck, who was accused of owning an enslaved Amerindian, the colonial officer John Daly decries such a transgression on the grounds that 'the aborigines of this Country ... are physically less able than Negroes, to undergo the hardships of Slavery'; as such, their enslavement is 'more repugnant to Humanity' than that of the African. ${ }^{11}$ In 1817, Daly would praise the Amerindian's keen senses, which made them, he believed, invaluable for tracking down runaway enslaved Africans. ${ }^{12}$ If the Black was understood as, in Calvin Warren's words, 'available equipment, equipment in human form', the Amerindian was a special kind of tool, delicate, and, in the wrong hands, breakable. ${ }^{13}$

After 1838, however, 'all other groups came to accord [the Amerindians] the lowest "racial" status in British Guiana ... on the grounds that they were uncivilized savages, lacking any culture of value'. ${ }^{14}$ By 1892 it was therefore possible for one writer, reflecting on the 1891 census, to claim that Amerindians were of 'little or no social value and their early extinction must be looked upon as inevitable'. ${ }^{15}$ Thus, as Black Creoles began to enter the cultural field and consequently became incorporated into the circuits of Guianese citizenship, Amerindians became increasingly dehumanised.

The making of Guianese reading audiences cannot be understood without attending to this process of exclusion, which I read in terms of two distinct conceptions of cultural tension, which Frank B. Wilderson III has called the 'rubric of conflict' and the 'rubric of antagonism'. The former refers to 'a rubric of problems that can be posed and conceptually solved', the latter to 'an irreconcilable struggle between entities, or positions, the resolution of which is not dialectical but entails the obliteration of one of the positions' ${ }^{16}$ In nineteenth-century British Guiana, multiple communities existed in conflictual relations which were often borne out in the periodical press. Underlying these conflicts, however, was an antagonism between the 'cultured' Guianese and the 'uncivilised' Amerindian, the cultural field's abject other. The Amerindian is effectively obliterated as a participant within the nineteenth-century Guianese public sphere; or rather, the public sphere is formed via the obliteration of the Amerindian. ${ }^{17}$

Consider, for example, an 1853 clash between the Royal Gazette and the Colonist - both state-sponsored periodicals - over how British law should 
handle the murder of one Amerindian by another. Where the editor of the Colonist advocated execution of the murderer as a means of deterring future incidences - 'the savage must be brought to dread the strong arm' - the editor of the Royal Gazette insisted that '[t]he moral obligation rests upon us to reclaim the untutored Indian, to bring him, if possible within those haunts where civilization may be found. Coax him, bribe him; we have taken possession of his heritage and we owe him this. But surely do not hang him. ${ }^{18}$ In the conflict between the editors, the Amerindian becomes a problem to be solved either rationally or morally. Yet the problem relies on the silence of the Amerindian, who has no voice in the debate, or whose voice remains inaudible within the structure of the cultural field. Indeed, I am suggesting, the field itself only coheres because of this silencing.

To put it differently: there was a colonial White press and a Creole Black press, but there was no Indigenous Red press. And over the course of the nineteenth century the mark of humanity would come to be tied to ownership of the means of cultural production and the capacity to disseminate cultural works - that is, the capacity to write and reach audiences whose humanity was defined by their literacy.

In offering up this argument I mean to supplement Shona Jackson's pathbreaking analysis of what she calls 'Creole indigeneity', whereby Creole claims to belonging erase those of Indigenous peoples. For Jackson, the primary means by which this erasure takes place is the elevation of labour as the mark of the human. Accepting the colonial capitalist association of labour with humanity, the Creole, Jackson argues, understands his belonging in terms of all he has done for the land, the work he has put into it. For Jackson, Amerindian labour has been rendered visible 'only as cultural, not the productive labor of economic development that allows the formerly enslaved and indentured to claim political belonging and right'. ${ }^{19}$ To Jackson's discussion I would add that a second discourse, in addition to the discourse of human labour, has continually served to legitimise Creole belonging and displace Guianese Amerindians: literary labour. Where Jackson claims a 'relative cultural embrace and simultaneous political marginalization' of Amerindians, I wish to suggest that the long-standing association between literacy and cultural legitimacy means that the status of Amerindian culture in British Guiana has never actually risen to the level of 'culture' at all. ${ }^{20}$

That some Amerindians in the nineteenth century could read and write, thanks to missionary colonialism, did nothing to correct the belief that Indigenous peoples were essentially illiterate. The missionary John Henry Bernau, for example, includes in his 1847 Missionary Labours in British Guiana a number of letters written by his former Amerindian students that attest to their control of written English. These students' hard work and diligent, continued reading of the Bible suggests to Bernau that they are 
'truly converted', where being Christianised is the precondition for becoming civilised. ${ }^{21}$ Unlike the born Christian, however, the convert is always in danger of, in Bernau's words, 'relapsing again into a savage state'.22 The 'savage' preliterate state is, according to this logic, the ontological condition of the Amerindian that haunts his existence as a literate subject.

The relationship between literacy and the rise of Creole indigeneity in the late nineteenth century is especially marked in the emergence of British Guiana's first national poet, Egbert Martin, best known to his readers as 'Leo'. Throughout the 1880s, before his death in 1890, Martin published two collections of poetry, a book of short stories, and numerous uncollected works in every major periodical in British Guiana. The Guiana Herald claimed he was 'far and away the first West Indian poet'. ${ }^{23}$ About this characterisation A. J. Seymour writes, 'I presume the writer means first in quality', although, given what I have suggested above, the description does double duty, not only glorifying Martin but also granting him a historical priority that displaces all Indigenous cultural texts that preceded the emergence of the Guianese republic of letters. ${ }^{24}$ As I discuss below, Martin was absolutely complicit in this act of erasure, which is particularly marked in his poems that sought to represent Amerindian peoples. In these poems it becomes clear how claiming a position as British Guiana's national (or proto-national) poet meant establishing oneself as its rightful native.

\section{Egbert Martin's Creole indigeneity}

Much of Martin's poetry is concerned with religious themes, but nowhere is the Protestant work ethic more visible than in the poem that closes his second volume. 'What Is the Good?' begins with the speaker expressing his doubt over his own poetic project, doubting whether one 'Can ... ever hope to compass / Any great thing by rhyme' (lines $7-8) .{ }^{25}$ He quells his own fears by reminding himself, and by extension his reader, that 'There is good in bare persistence', that literary labour, like any other form of labour, is its own reward:

With the pen, or tool of labor,

Art or industry, - whate'er

Comes into our lives as duty

Do it - heedless of the care. (lines $25-8)^{26}$

If, as Jackson argues, labour defines Creole belonging, Martin makes clear that the pen is one - and for him the primary - means by which belonging is enacted. And, consequently, it is a means by which the Amerindian is exiled. 
If grounding humanity in literacy serves to expel from the category of the human Indigenous peoples understood as essentially illiterate, Creole writing about Indigenous peoples doubles this process. The forms of this second expulsion are diverse and reflect diverse forms of belonging, different ways of asserting oneself as the primary inhabitant of the land. Across Martin's short career, we see a shift in both the representation of the Amerindian and a shift in the terms by which he defines himself as an Emersonian 'representative man', the voice of British Guiana. These two shifts thoroughly inform one another.

Martin's first collection, Leo's Poetical Works (1883), sought to, in the words of its preface, 'reach the outward ears and sink deeply into the hearts of some of his fellow-pilgrims through this "valley of tears" carrying comfort to the sorrowful and oppressed; hope to the languid and desponding; strength to the weak and weary; light to those who sit in darkness; and cheerful encouragement to the "weary in well-doing". ${ }^{27}$ Throughout the collection Martin employs this kind of religious rhetoric, where the bonds between Christian subjects allow for sympathetic understanding. Within this larger poetic project, the Amerindian functions to consolidate the Christian Creole community by virtue of its alterity.

'The Indian's Return', for example, describes a solitary Indian who returns after many years to a desolate village, cut off from the circuits of sympathy - 'His friends were gone, his kindred fled' (line 4) - and, worse, from the comfort that Christian faith provides the civilised Creole subject:
Did he know the faith which a Christian knows?
Did he hope for a happier sphere?
There would have been far less of sadness,
And more of trust, and more of gladness;
But he only knew the pain which flows
From a deep and fixed despair. (lines 25-3028

The companion to this piece, 'The Hammock Maker: An Indian Eclogue', presents Creole readers with another solitary Amerindian figure, an old hammock-maker who stands apart from the 'Younger braves' (line 15). ${ }^{29}$ Like the figure in 'The Indian's Return', the hammock-maker suffers the pain of those outside the fold of Christianity: 'For his heart is constant sighing / In a superstitious dread; / Longing, longing to be dying, / Fearing, fearing to be dead' (lines 45-8). ${ }^{30}$ If such figures elicit pity from Creole readers, they do not create the ties of fellow-feeling reserved for those 'fellow-pilgrims' whom Martin describes in his preface.

Martin's first collection was not as well received as he had hoped. In the preface to his follow-up collection, the 1886 volume Leo's Local Lyrics, he 
refers to criticisms of his earlier work, alluding to a particularly scathing review in London's Saturday Review, which read: “Leo's" poems have not even the thinnest guise of poetry. They illustrate a strain of trite, and often silly reflection, and a sentiment of "goodiness" that is nauseating." 31 As a consequence of this poor reception, Martin designed his second collection to appeal to a wider public, emphasising local British Guianese culture rather than the religious themes of his first book. ${ }^{32}$ In doing so, he develops an alternative means of representing indigeneity and, in turn, authorising Creole belonging.

While much of Martin's biography, including what he read, remains a mystery, we know from an introductory note to his poem 'The Kaieteur Falls' that he had gained some knowledge of Amerindian peoples from Everard im Thurn's Among the Indians of Guiana: Sketches Chiefly Anthropologic from the Interior of British Guiana (1883). ${ }^{33}$ Of particular interest to Martin seems to have been im Thurn's account of animism and especially his discussion of spirits dwelling within objects: 'To the Indians,' writes im Thurn, 'inanimate objects have spirits which differ not at all in kind from those of men.' 34 This section of im Thurn's study likely informed the first part of Martin's collection, titled 'Tropical Studies'. He writes in the preface to Leo's Local Lyrics:

Anyone at all familiar with current Creole superstitions and the peculiar beliefs of Indian animism, must have noticed that a childishly simple credulity in the universal existence of spirits characterizes them all. Not only that, but the possible influences of these unseen existences on their lives, actions, dreams, etc., are all taken into account. As education advances, these beliefs, of course, give way, although they still exist to a very appreciable extent. ${ }^{35}$

'I have tried to weave this dim, far-off, intangible - call it - spirituality into a few of the tropical studies', Martin continues, and 'weave' is perhaps an appropriate verb. Martin structures many of his tropical studies as 'childishly simple' songs, weaving naivete into his form. ${ }^{36}$ 'The Creek', for example, begins:

Across the creek the midnight moonlight breaks, Along the creek the witching moonlight breaks, 'Tis like a soul that dreams but never wakes.

The creek it hath a spirit in its breast, It hath a secret spirit in its breast, And oft it moves upon the water's crest.

And oft it sings in dreadful notes and low, In thrilling, sighing, pining notes and low, That make you shudder as you hear them flow. 
And that is why the village people find, And that is why the simple people find

A something in the creek that's like the wind;

And that is why the little children flee, And that is why the merry children flee, From by its side when evening's dusk they see. (lines 1-15) ${ }^{37}$

Here and in other tropical studies, Martin offers heavy-handed anaphora and simple masculine rhymes that reproduce formally the innocence that he projects on to the natives, the 'simple people', as he puts it.

Tropical studies such as 'The Creek' move well beyond Martin's earlier representative strategy, whereby the Amerindian is situated outside the circuits of Christian sympathy, an object of pity but not a subject with whom feelings are shared. The later poems, while working to incorporate or 'weave' into his poems the Amerindian beliefs transmitted to him via the European im Thurm, effectively unincorporate the Indigenous subject, who no longer even rises to the level of object of knowledge. It thus becomes possible in other tropical studies for Martin to adopt the persona of one who subscribes to the animism that we know he dismissed as childish. In 'The Palm-Soul', for example, Martin presents a first-person narrator who embraces a palm tree and feels its spirit. The speaker then reflects: 'Nature feels / From mount to deep one sympathy, / One sense thro' all creation steals, / One sentiment of unity' (lines 12-15)..$^{38}$ Read charitably, such poems represent an effort to reconcile Martin's cherished Christianity with the version of animism he ascribed to the Amerindian peoples. Yet such reconciliation, of course, can only take place on terms established by the Creole poet.

To be clear: in laying out this critique of Martin's poetic project, I do not wish to implicate Creole subjects alone for the displacement of the Guianese Amerindians; rather I want to show how such displacement is the consequence of colonial entanglements that begin with European imperialism. Here it must be remembered that Martin evacuates the native from his tropical studies in accordance ... with public taste', where 'public' meant not only local Guianese Creoles but also representatives from the centre of literary and imperial power who had dismissed his first collection. ${ }^{39}$ And, indeed, the strategy worked: the same journal that had derided Leo's Poetical Works praised the second collection's 'untutored frankness', suggesting that Leo had successfully inhabited the position of raw being he attributed to the Amerindian. ${ }^{40}$ Thus, we need to understand Creole indigeneity as a form of appeal for recognition by Creole subjects to centres of imperial power. It is not just about Creole claims to belonging, but the acknowledgment of those claims by the wider, whiter world.

Decolonisation, then, involves refusing altogether recognition-based politics, where the Creole expects recognition from the Global North and offers 
recognition to Amerindian communities. To speak of 'recognition' in the context of Indigenous peoples is, of course, usually to speak of political recognition..$^{41}$ Yet, since at least the nineteenth century, the matter of cultural recognition - that is, how cultural products are legitimised within a national and transnational marketplace - has been powerful in delegitimising Indigenous claims to sovereignty. Culture, thus understood, is never merely superstructural. Rather, it informs all possible relationships between settler, Creole, and Indigenous peoples. What counts as culture must be radically rethought, then, beginning with the privileging of the written, which has long served as a mark of Creole belonging.

\section{'[C]an't hear, can't see'}

Writing, according to the late Lakota political activist Russell Means, has been 'one of the white world's ways of destroying the cultures of non-European peoples'. ${ }^{42}$ Without bolstering what Adrien Delmas describes as ' $[t]$ he anthropological myth of native orality, generalised to all that was not European', it remains for the settler-scholar to acknowledge that a narrow conception of writing has served to authorise certain forms of belonging and delegitimise others. ${ }^{43}$ Such an acknowledgment, however, should not be mistaken for unlearning writing in favour of learning to 'hear' or learning to 'see' Indigenous peoples. Reversing the process by which Indigenous peoples are deemed ontologically illiterate, Means deems the white world essentially incapable of approaching Indigenous cultures: 'I don't really care whether my words reach whites or not. They've already demonstrated through their history that they can't hear, can't see, they can only read. ${ }^{44}$

If this seems an extreme position to take, we might consider how the effort to 'see' and 'hear' the Amerindian is woven into the history of nineteenthcentury British Guiana. Im Thurn's volume, the same one that Martin drew upon for his tropical studies, includes over fifty plates and woodcuts depicting everything from 'A Macusi in Full Dancing Dress' to a 'Cobungru Woman, showing Leg-bands'. He provides readers with a table of 'Examples of the Chief Indian Languages of Guiana', presenting nine English words as they are spoken by seven different tribes. 'Unfortunately,' he writes, 'I have no Arecuna vocabulary at my disposal; but the language differs merely by very slight varieties of pronunciation from the Macusi. ${ }^{35}$ Readers are left to presume the unimportance of these 'very slight varieties'.

In addition to producing his ethnographic volume, im Thurn organised the British Guiana collection for the 1886 Colonial and Indian Exhibition in London. Millions of attendees were afforded the opportunity to gaze upon Indigenous artefacts from across the colony. Among those artefacts was a 
group of Amerindians, 'living ethnological displays' who built and then inhabited replica Amerindian villages. ${ }^{46}$ The Report of the Royal Commission for the Colonial and Indian Exhibition (1886) provides some details about these 'Red Indians' of British Guiana, including their names, tribal affiliations, ages, and their roles within their respective communities; ten Amerindians in all, each 'baptized in the Church of England Mission'. Among the list are two entries who provide some indication of the ways that efforts to 'see' and 'hear' Indigenous peoples are limited by the history of articulating humanity in terms of literacy: Anthony Gordon, age 24, a 'Macoosi wood-cutter', and his cousin, Maria, age 8, 'Acowoio'. Anthony, we are told, 'reads and writes in English' and Maria 'reads and writes a little'.47

\section{Notes}

1 E.M. [Egbert Martin], 'By the Lake: An Indian Eclogue’, Colonist (8 April 1882), n.p., lines 46-51.

2 The attribution of this praise to Schomburg comes from Eric D. Walrond's 'Visit to Arthur Schomburg's Library Brings out Wealth of Historical Information', which was first published in Negro World on 22 April 1922 and reprinted in Tony Martin (ed.), African Fundamentalism: A Literary and Cultural Anthology of Garvey's Harlem Renaissance (Dover: The Majority Press, 1991), p. 317.

3 The term 'Amerindian' is widely used in discussions of British Guiana as a means of distinguishing Indigenous peoples of the region from the Indians who were brought to the colony in large numbers by the British as indentured laborers in the post-emancipation era.

4 Prospectus, Demerara Daily Chronicle (10 November 1881), n.p.

5 Jon Klancher, The Making of English Reading Audiences, 1790-1832 (Madison: University of Wisconsin Press, 1983), p. 46.

6 The phrase 'imagined community' comes, of course, from Benedict Anderson's Imagined Communities: Reflections on the Origin and Spread of Nationalism (London: Verso, 1983).

7 See, in addition to Klancher, Jared Gardner, The Rise and Fall of Early American Magazine Culture (Urbana: University of Illinois Press, 2012), especially p. 78: in America, Gardner writes, " $[\mathrm{a}] \mathrm{s}$ the ideals of the Revolution quickly gave way to a rising tide of factionalism in the years following the ratification debate, the periodical would become invested with even greater hopes and fantasies as refuge, an asylum, where the best possibilities of the republic could be nourished'.

8 Nigel David Westmaas, 'A Mirror of Social and Political Ferment: The Newspaper Press of Guyana: 1838-1899' (PhD dissertation, Binghamton University, State University of New York, 2006), pp. 7-10.

9 Westmaas, 'A Mirror of Social and Political Ferment', p. 8.

10 See Mary Noel Menezes, The Amerindians in Guyana, 1803-73: A Documentary History (London: Frank Cass, 1979), p. 161: 'In 1793 a special Ordinance 
prohibited the enslavement of Indians or the offspring of Indians.' This ordinance was honoured even after the British took control of the colonies in 1803.

11 Menezes, The Amerindians in Guyana, p. 164.

12 Menezes, The Amerindians in Guyana, p. 11.

13 Calvin L. Warren, Ontological Terror: Blackness, Nibilism, and Emancipation (Durham: Duke University Press, 2018), p. 28.

14 Andrew Sanders, 'British Colonial Policy and the Role of Amerindians in the Politics of the Nationalist Period in British Guiana, 1945-68', Social and Economic Studies, $36: 3$ (1987), 81. It should be noted that there was, prior to emancipation, a historically significant population of free Blacks in Guyana. See Adele Perry, Colonial Relations: The Douglas-Connolly Family and the Nineteenth-Century Imperial World (Cambridge: Cambridge University Press, 2015), pp. 56-7: 'between 1810 and 1830 the population of free people of color in Berbice, Demerara, and Essequibo grew by about 70 percent, and easily overtook the White population'.

15 E. D. Rowland, 'Census of British Guiana, 1891', Timehri, 6 (June 1892), 56, quoted in Mary Noel Menezes, British Policy towards the Amerindians in British Guiana, 1803-1873 (Georgetown: Caribbean Press, 2011), p. 42.

16 Frank B. Wilderson III, Red, White \& Black: Cinema and the Structure of U. S. Antagonisms (Durham: Duke University Press, 2010), p. 5.

17 For Wilderson, writing in the context of the United States, it is the Black American who exists in antagonistic relationship to the human, while ' $t \mathrm{t}$ ]he Red, Indigenous, or "Savage" position exists liminally as half-death and half-life between the Slave (Black) and the Human (White, or non-Black)' (Red, White \& Black, p. 23). While a fuller discussion of this position lies beyond the scope of the present chapter, suffice it to say I do not believe that this schema holds up in the context of nineteenth-century British Guiana or modern-day Guyana. For a critique of Wilderson's understanding of indigeneity, see Iyko Day, 'Being or Nothingness: Indigeneity, Antiblackness, and Settler Colonial Critique', Critical Ethnic Studies, 1:2 (2015), 102-21.

18 Menezes, British Policy towards the Amerindians in British Guiana, pp. 172-3.

19 Shona N. Jackson, Creole Indigeneity: Between Myth and Nation in the Colonial Caribbean (Minneapolis: University of Minnesota Press, 2012), p. 10.

20 Jackson, Creole Indigeneity, p. 7.

21 John Henry Bernau, Missionary Labours in British Guiana: With Remarks on the Manners, Customs, and Superstitious Rites of the Aborigines (London: J. F. Shaw, 1847), p. 185: 'Christianize them first,' writes Bernau, 'and civilization, really deserving of the name, is sure to follow.'

22 Bernau, Missionary Labours in British Guiana, p. 215.

23 This and other praises were listed on the back page of Martin's second collection, Leo's Local Lyrics (Georgetown: Baldwin and Co., 1886), n.p.

24 A. J. Seymour, 'The Literary Tradition: The Poetry of Egbert Martin (Leo)', in Kyk-Over-Al, Volume 1, Issues 1-3, December 1945-December 1946 (Georgetown: Caribbean Press, 2013), p. 199.

25 Leo [Egbert Martin], 'What Is the Good?', Leo’s Local Lyrics, pp. 74-5. 
26 Leo, 'What Is the Good?', Leo's Local Lyrics, pp. 74-5.

27 Leo, Leo's Poetical Works (London: W. H. and L. Collingridge, 1883), n.p.

28 Leo, 'The Indian's Return', Leo's Poetical Works, pp. 202-3.

29 Leo, 'The Hammock Maker: An Indian Eclogue', Leo's Poetical Works, pp. 204-5.

30 Leo, 'The Hammock Maker', Leo's Poetical Works, pp. 203-5.

31 [Anon.], 'Recent Poetry', Saturday Review, 57 (3 May 1884), p. 587.

32 For a fuller discussion of Martin's response to this criticism, see Manu Samriti Chander, Brown Romantics: Poetry and Nationalism in the Global Nineteenth Century (Lewisburg: Bucknell University Press, 2017), pp. 44-62.

33 Leo [Egbert Martin], 'The Kaieteur Falls', Argosy (5 July 1884), p. 2. Martin introduces his poem with a quotation from im Thurm's 'lately published, admirable work'.

34 Everard im Thurn, Among the Indians of Guiana: Sketches Chiefly Anthropologic from the Interior of British Guiana (London: Keegan, Paul, Trench, and Co., 1883), p. 349.

35 Leo, 'Preface', Leo's Local Lyrics, pp. v-vi.

36 Leo, 'Preface', Leo's Local Lyrics, pp. v-vi.

37 Leo, 'The Creek', Leo's Local Lyrics, pp. 3-8.

38 Leo, 'The Palm-Soul', Leo's Local Lyrics, pp. 18-19.

39 Leo, 'Preface', Leo's Local Lyrics, p. v.

40 [Anon.], 'New Books and Reprints', Saturday Review (6 November 1886), p. 635.

41 For an excellent discussion of the limits of the politics of recognition in Indigenous activist movements, see Glen Coulthard, Red Skin, White Masks: Rejecting the Colonial Politics of Recognition (Minneapolis: University of Minnesota Press, 2014), especially chapter 4.

42 Russell Means, 'The Same Old Song', in Ward Churchill (ed.), Marxism and Native Americans (Boston: South End Press, 1992), p. 19.

43 Adrien Delmas, 'Introduction: The Written Word and the World', in Adrien Delmas and Nigel Penn (eds), Written Culture in a Colonial Context: Africa and the Americas 1500-1900 (Leiden: Brill, 2012), p. xxviii.

44 Means, 'The Same Old Song', p. 19.

$45 \mathrm{Im}$ Thurn, Among the Indians of Guiana, p. 166.

46 Sara Albuquerque, 'Glimpses of British Guiana at the Colonial and Indian Exhibition, 1886', Culture and History Digital Journal, 5:1 (2016), n.p., http://cultureandhistory.revistas.csic.es/index.php/cultureandhistory/article/view/97/333 (accessed 10 January 2020).

47 Albuquerque, 'Glimpses of British Guiana at the Colonial and Indian Exhibition, 1886', n.p. 